\title{
THE MOVES OF INDONESIAN APPLICATION LETTERS
}

\author{
Sri Hapsari Wijayanti \\ Faculty of Economic, Atma Jaya Catholic University, \\ Jln. Jend. Sudirman no. 51, Karet Semanggi, DKI Jakarta 12930, Indonesia \\ sri.hapsari@atmajaya.ac.id
}

Received: $18^{\text {th }}$ November 2016/ Revised: $28^{\text {th }}$ November 2016/ Accepted: $9^{\text {th }}$ January 2017

How to Cite: Wijayanti, S. H. (2016). The Moves of Indonesian Application Letters. Lingua Cultura, 11(1). 39-45. http://dx.doi.org/10.21512/lc.v11i1.1726

\begin{abstract}
Job application letter is one of many types of written communication. Every context has its own way to write application letter. This article aimed to know the pattern of moves of solicited and unsolicited job application letters, as well as to identify the structure patterns of moves and language used in Indonesian application letters generally. The corpus were 62 application letters. The data were analyzed by using quantitative and qualitative descriptive methods. The research finds that the Indonesian application letters consist of nine obligatory moves: opening salutation, offering candidature, introducing candidature, promoting candidature, enclosing documents, willingness to action, stressing the facts, thanking, and closing salutation. The movement structure has similarity with the application letter from other countries as previous studies. The difference lies in the label of used terms. The implicitness and inability to express self-quality could be referred to the Indonesian culture known as modesty and inhibition in telling about oneself.
\end{abstract}

Keywords: application letters, Indonesian application letters, genres, written communication

\section{INTRODUCTION}

In daily life, people use language to get effective communication for many functions. The communicative event among the members of society that interact each other to reach the purposes of communication is known as genre. Genre, according to Swales (1990), is described as, "A class of communication events, the members of which share some sets of communication purposes $[\ldots]^{\text {" }}$

"The genre names inherited by the parent discourse community..." (Sadeghi \& Samuel, 2013). Genre refers to, "A sociolinguistics activity in which the participants are able to achieve goals" (Henry \& Roseberry, 2001). In short, genre is a communicative event to reach the goal of the participants. Understanding genre means understanding the texts and the contexts. (Bhatia, n.d.).

There are abundant studies on how people in society communicate through the analysis method of genre (Khan $\&$ Tin, 2012). It is originated from Swales' research related to teaching English for Specific Purposes (ESP), particularly the introduction analysis of academic writing (Cook, 2011). Since then, there have been many researchers of genre analysis from various professional and academic settings. One of the professional genres which get much attention from many researchers is job application letters.

A job application letter is one kind of genres that aims to promote the job applicants to attract the attention or invite responses from employers (Bhatia, 1993). The letter is based on the applicant willingness (unsolicited letters) or based on the information from media or someone known (solicited letters). The application letter becomes an introductory letter accompanying the resume.

Genre analysis uses two approaches: one focus on text analysis and the other focus on social contexts or discourse community. Malinowski, as cited by Nkemleke (2004) pointed out that to understand text, the understanding of context on how the text occurred is needed. In social perspective, genre is considered as a dynamic thing that changes following the need of communication users. A genre is described as a communicative event that uses language form and content as a representation of communication purposes realized by the same society members:

A genre comprises a class of communication events, the members of which share some set of communication purposes. These purposes are recognized by the expert members of the parent discourse community and thereby constitute the rationale for the genre. This rationale shapes the schematic structure of the discourse and influences and constraints choice of content and style (Swales, 1990).

Job application letter is a form of written communication. Every context has its own way to write application letter. Writing an application letter is not different with writing business letters, such as product offer, advertisement, company brochure, leaflet (Khan \& Tin, 2012) and a complaint letter (Nkemleke, 2004). In a cover letter, there is a persuasive element to persuade the 
employers to do an action to call the applicants for an interview (Gillaerts, 2003) or invite the applicants to join the recruitment procedure (Guffey \& Du-Babcock, 2008). Table 1 shows that a job application letter has the same organization with the purchasing letter. It starts with the way of the writer attracts the reader's attention, then the writer introduces self-qualification, give the proof, and finally ends by pushing the reader to do an action.

Since the letter is influential, the writer of an application letter should have ability to promote himself by showing the compatibility of the jobs with the requirements (Petty \& Cacioppo, 1986, cited from Soroko, 2012). This confirms, following Bhatia's (1993) statement, cited from (Al-Ali, 2006):
The type of genre whose main communication function is to make relevant the qualification and professional experience of the applicant to the specifications of the job advertisement in order to persuade the employer to hire the applicant.

Genre of job application letter has long attracted the attention to be studied from various views. Many previous researchers have studied how members of a community to use their language in job application letters. Anything else has observed job application letters in crosscultural or compared between application letter and other business letter such as the letter of intent, product sale or purchase or service, and also studied the language use in

Table 1 The Comparison of Business Promotion Letter and an Application Letter

\begin{tabular}{ll}
\hline Business Promotion Letter & Application Letter \\
\hline Attract attention & Attract attention \\
Introduce the product & Introduce the qualification \\
Give the proof & Give the proof \\
Push an action & Push an action \\
\hline
\end{tabular}

(Source: Purwanto, 2011)

Table 2 Recapitulation of Previous Studies on Moves Based on Contexts

\begin{tabular}{|c|c|c|c|c|c|c|}
\hline & $\begin{array}{c}\text { Bhatia (1989) } \\
\text { cited from Khan } \\
\text { \& Tin (2012) } \\
\end{array}$ & Bhatia (1993) & Henry \& Roseberry (2001) & Al-Ali (2006) & Soroko (2012) & Khan \& Tin (2012) \\
\hline Corpus size & 200 & Not known & 40 & 90 & 182 & 26 \\
\hline \multirow{5}{*}{$\begin{array}{l}\text { Context } \\
\text { Move } \\
\text { scheme }\end{array}$} & South Asia & Not known & South East Asia, UK, USA & Jordan & Poland & Pakistan \\
\hline & Self-glorification & Establishing credentials & Opening & Opening & Reference to the advertisement & Addressing \\
\hline & Self-degradation & $\begin{array}{l}\text { Introducing the } \\
\text { candidature. }\end{array}$ & Referring to a job & Referring to the source of & Showing interest in the offer & Referring to the source of \\
\hline & $\begin{array}{l}\text { Adversary } \\
\text { glorification }\end{array}$ & Offering candidature & Offering candidature & Applying for the job & $\begin{array}{l}\text { Emphasizing the match } \\
\text { between the author of letter } \\
\text { and the prospective emplovee }\end{array}$ & Establishing credentials: \\
\hline & & $\begin{array}{l}\text { Essential detailing of } \\
\text { candidature }\end{array}$ & Stating reasons for applying & Glorifying the institution & $\begin{array}{l}\text { Indication of the applicant's } \\
\text { professional skills }\end{array}$ & Listing qualifications \\
\hline \multirow[t]{14}{*}{ v } & & $\begin{array}{l}\text { Indicating value of the } \\
\text { candidature }\end{array}$ & Stating availability & Promoting candidature & $\begin{array}{l}\text { description of the applicant's } \\
\text { educational background and } \\
\text { professional skills }\end{array}$ & Predicting success \\
\hline & & Offering incentives & Promoting the candidate & Enclosing documents & $\begin{array}{l}\text { description of the applicant's } \\
\text { positive personality traits }\end{array}$ & Detail experiences \\
\hline & & Enclosing documents & $\begin{array}{l}\text { Listing relevant skills, } \\
\text { abilities }\end{array}$ & Invoking compassion & $\begin{array}{l}\text { Demonstration of the } \\
\text { applicant's professional } \\
\text { experience }\end{array}$ & Highlighting personality \\
\hline & & Soliciting response & $\begin{array}{l}\text { Stating how skills, abilities } \\
\text { were obtained }\end{array}$ & Soliciting response & $\begin{array}{l}\text { Listing the benefits to the } \\
\text { company of hiring the } \\
\text { applicant }\end{array}$ & $\begin{array}{l}\text { Emphasizing skills and } \\
\text { achievements }\end{array}$ \\
\hline & & Using pressure tactics & Listing qualifications & $\begin{array}{l}\text { Indicating willingness for } \\
\text { personal interview }\end{array}$ & Expectation of further contact & $\begin{array}{l}\text { Referring the enclosed } \\
\text { documents/CV }\end{array}$ \\
\hline & & Ending politely & $\begin{array}{l}\text { Naming present job } \\
\text { Predicting success }\end{array}$ & Ending politely & Expression of respect & $\begin{array}{l}\text { Offering candidature } \\
\text { Glorifying the employer }\end{array}$ \\
\hline & & & Listing publications & & & Ending politely \\
\hline & & & $\begin{array}{l}\text { Giving reasons for leaving } \\
\text { present job }\end{array}$ & & & $\begin{array}{l}\text { Soliciting responses } \\
\text { (favorable) }\end{array}$ \\
\hline & & & $\begin{array}{l}\text { Demonstrating knowledge } \\
\text { of target position }\end{array}$ & & & Expressing gratitude \\
\hline & & & Polite ending & & & Closing the courtesy \\
\hline & & & Welcoming response & & & \\
\hline & & & Inviting favorable & & & \\
\hline & & & $\begin{array}{l}\text { consideration } \\
\text { Thanking }\end{array}$ & & & \\
\hline & & & $\begin{array}{l}\text { Offering to provide further } \\
\text { information }\end{array}$ & & & \\
\hline
\end{tabular}

(Source: cited from Khan \& Tin (2012), added by researcher) 
the opening and closing. However, the move and language of application letter written in Bahasa Indonesia still have not been studied yet. This study has implication for the teacher to teach effective writing for application letters. The following Table 2 shows the previous studies on move in an application letter from several contexts.

This study uses a theory of genre analysis from Bhatia (1993). Genre analysis is used widely to identify move components by many researchers because it is more powerful in interpreting structure of text moves and lexical grammatical components (Kong, 1998, cited from Al-Ali, 2006). Genre analysis is defined as a linguistic realization of some social activity (Cannor, 1996, cited from Al-Ali, 2006). In language society, each communicative event uses different moves based on the purpose of communication (Bhatia, 1993; Swales, 1990, cited by Al-Ali, 2006). The communication purpose in an application letter is the reason why the letter is written (Sadeghi \& Samuel, 2013). This article ha several aims, which are (a) to know pattern of moves of solicited and unsolicited application letters; (b) to identify structure patterns of moves and language used in Indonesian application letters generally.

\section{METHODS}

The corpus is job application letters within the period 2012-2014 that have been written by Indonesian native speakers. The writer of the letter aims to apply for the position as lecturer in one of private university in Jakarta. The letters were sent to Human Resouce Development (HRD) office, the head of department, the dean of the faculty, rector, or vice rector of the private university. The corpus consists of 62 application letters consisting of: 33 letters written by males and 29 letters by females. Most of them (43 persons) wrote the letters based on their willingness (unsolicited letter). The data can be seen in Table 3.

Table 3 The Amount of Sample Based on Gender

\begin{tabular}{cccc}
\hline Gender & Solicited & Unsolicited & Amount \\
\hline Male & 12 & 21 & 33 \\
Female & 7 & 22 & 29 \\
Total & 19 & 43 & 62 \\
\hline
\end{tabular}

The application letters were written by the applicants having bachelor and master degrees or the ones pursuing their master and doctoral degrees. Some of them have some work experiences as lecturer or other occupations. The letters which are written based on the job vacancy at mass media or only information given by someone are called solicited letters. Those information sources come from Kompas daily (2012), website joblist.com (2013), and jobstreet.com (2014). The letters written based on the job vacancy usually require the qualification needed by the employers. In this study, the personal information of the applicant is not revealed.

The procedure of this study was conducted by categorizing the move structures based on communication function and then identifying move's language used. The identification was performed by reading and checking through the data. To reduce the complexity in categorizing the data, each data was coded based on types of the letters (solicited letters/SL or unsolicited letters/US; the number of list of SL/US; the number of direction of the letters (rector/R, vice rector/VR, dean/D, vice dean/WD, head of department $/ \mathrm{K}$, or head of HRD); and sex (F/M)). For example: (SL/37/D-12/F). In identifying the move structure, this study hired an assistant from the same major (as a coder) and made a consensus if there is a difference in perception.

The techniques of analysis were qualitative and quantitative descriptive methods. Qualitatively, the data were analyzed with content analysis by identifying moves based on functional semantic criteria. This is based on the concept from Dubois (1997), cited by Al-Ali (2006) that stated, "Move is functional semantic unit whose length depends on the purpose of the writer and its language realization. "

A move can be applied in one sentence or more, or even in one clause of phrase (Swales, 1990). The communication function of each unit was connected with the purpose of the application letter in general. Quantitatively, data were analyzed by counting the frequency and its percentage occurrence of each move and organization models of application letters.

\section{RESULTS AND DISCUSSIONS}

Generally, the application letters in Indonesian consist of 15 moves (Table 4): 10 moves are obligatory move and 5 moves are arbitrary move. The application letters were written as the company or institution advertisements (solicited letter) contained shorter moves than the ones that based on the applicants' willingness (unsolicited letter). The number of moves in solicited letters is 11; while in unsolicited letters is 14 . The only move that is not found in the unsolicited letter is the referring to source information. Moves that are not found in solicited letters are (a) stating reasons, (b) offering preference, (c) praying, and (d) offering service.

Table 4 The Move Structures Based on Source of Job Vacancy

\begin{tabular}{lcc}
\hline $\begin{array}{l}\text { Move Structure } \\
\text { (Khan \& Tin, 2012) }\end{array}$ & $\begin{array}{c}\text { Solicited } \\
\text { letters }\end{array}$ & $\begin{array}{c}\text { Unsolicited } \\
\text { letters }\end{array}$ \\
\hline $\begin{array}{l}\text { Opening salutation } \\
\text { Referring to source information }\end{array}$ & $\mathrm{V}$ & $\mathrm{V}$ \\
Stating reasons & $\mathrm{V}$ & $\mathrm{V}$ \\
Offering candidature & $\mathrm{V}$ & $\mathrm{V}$ \\
Introducing candidature & $\mathrm{V}$ & $\mathrm{V}$ \\
Promoting candidature & & $\mathrm{V}$ \\
Offering preference & $\mathrm{V}$ & $\mathrm{V}$ \\
Glorifying institution & $\mathrm{V}$ & $\mathrm{V}$ \\
Enclosing documents & $\mathrm{V}$ & $\mathrm{V}$ \\
Willingness to action & $\mathrm{V}$ & $\mathrm{V}$ \\
Stressing the facts & & $\mathrm{V}$ \\
Praying for employer & & $\mathrm{V}$ \\
Offering service & $\mathrm{V}$ & $\mathrm{V}$ \\
Thanking & $\mathrm{V}$ & $\mathrm{V}$ \\
Closing salutation & &
\end{tabular}




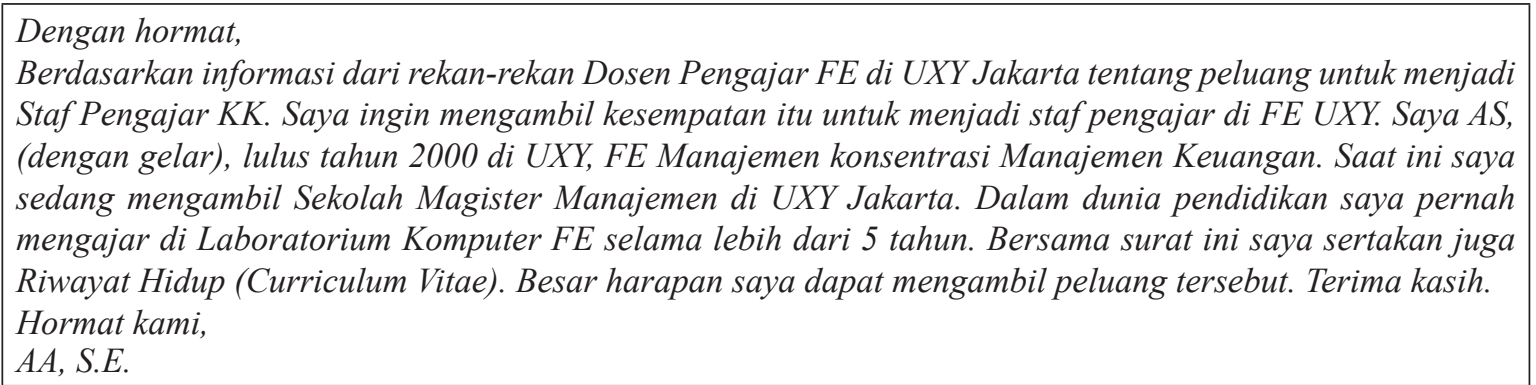

Dear Sir, [opening solutation]
Based on the information from lecturer colleagues at Economic Faculty of UXY Jakarta about the
opportunity to be a lecturer of KK [referring to source information], I want to take the chance to be a lecturer
at Economic Faculty of UXY Jakarta. [offering candidature]. I, AS (with the degree), graduating in 2000
from Management Department Economic Faculty of UXY, majored at Finance Management. Right now, I
am enrolling Management Master at UXY Jakarta [introducing candidature]. In education, I have ever taught
at Computer Laboratory of Economic Faculty for more than 5 years [promoting candidature]. Enclosed are
my curriculum vitae [enclosing documents]. I really hope that I am able to take that opportunity. [willingness
to action]
Thank you [thanking]
Sincerely,
AA (with degree)

From all of the observed data, it is found that the job application letters (solicited and unsolicited) consist of moves which are detailed in Table 5.

Table 5 Move Structure in Job Application Letter

\begin{tabular}{lcc}
\hline Move Structure & $\begin{array}{c}\text { Total } \\
(\mathbf{n}=\mathbf{6 2})\end{array}$ & $\begin{array}{c}\text { Total } \\
\mathbf{( \% )}\end{array}$ \\
\hline Opening salutation & 57 & 92 \\
Referring to source information & 19 & 31 \\
Promoting candidature & 34 & 55 \\
Glorifying institution & 3 & 5 \\
Offering candidature & 49 & 79 \\
Introducing candidature & 43 & 69 \\
Offering preference & 7 & 11 \\
Offering service & 1 & 2 \\
Glorifying institution & 1 & 2 \\
Praying for employer & 3 & 5 \\
Stating reasons & 4 & 6 \\
Enclosing documents & 39 & 63 \\
Willingness to action & 39 & 63 \\
Stressing the facts & 34 & 55 \\
Thanking & 60 & 97 \\
Closing salutation & 58 & 94 \\
\hline
\end{tabular}

By observing the frequency of occurrence in the letter, glorifying institution in obligatory move is only $5 \%$ out of the whole data (see Table 5). In conclusion, referring to Table 4, there are nine obligatory moves appear in a high percentage, which are: (1) opening salutation, (2) offering candidature, (3) introducing candidature, (4) promoting candidature, (5) enclosing documents, (6) willingness to action, (7) stressing the facts, (8) thanking, and (9) closing salutation.

From those nine moves, the applicants are able to elaborate the message by adding the arbitrary moves, such as referring to source information (in solicited letters); stating reasons, glorifying institution, praying for employer, offering preference, and offering service (in unsolicited letters). In this research, the arbitrary moves in unsolicited letters are also found in the solicited letters.

The differences with the previous studies are shown in Table 6. Which shows that some moves found in the research are similar with the ones found in the previous studies although the positions are not the same. For example, in this study, move of offering candidature occurred after or before referring to source information. Yet, this move occurred after referring to the source of information (Henry \& Roseberry, 2001). Therefore, there is a similar move but in different position.

Another move that is also similar to the previous studies is promoting candidature although with the different naming: establishing credentials (Bhatia, 1993), while Soroko (2012) gave detailed description about this move into several steps. Move of promoting candidature in this research has concluded the steps: indication of the applicants' professional skills, description of the applicants' educational background and professional skills, description of the applicants' positive personality traits (Soroko, 2012).

The difference of move naming was also found among this research and the previous studies. For example, in this research, the position of the jobs applied is called offering candidature but Soroko (2012) named it showing interest in the offer. Moreover, this research has the term willingness to action, but other studies has soliciting response (Bhatia, 1993; Al-Ali, 2006; Khan \& Tin, 2012), or welcoming response (Henry \& Roseberry, 2001). 
Table 6 The Differences of the Current Study and the Previous Studies

\begin{tabular}{|c|c|c|c|c|c|c|}
\hline Move & $\begin{array}{l}\text { Bhatia } \\
(1993)\end{array}$ & $\begin{array}{l}\text { Henry \& Roseberry } \\
\text { (2001) }\end{array}$ & Al-Ali (2006) & $\begin{array}{l}\text { Soroko } \\
(2012)\end{array}$ & $\begin{array}{l}\text { Khan \& Tin } \\
\text { (2012) }\end{array}$ & $\begin{array}{c}\text { This study } \\
\text { (2015) }\end{array}$ \\
\hline - Opening salutation & & $\mathrm{V}$ & $\mathrm{V}$ & & & $\mathrm{V}$ \\
\hline - Referring to source & & $\mathrm{V}$ & V & $\mathrm{V}$ & $\mathrm{V}$ & $\mathrm{V}$ \\
\hline $\begin{array}{l}\text { information } \\
\text { Stating reasons }\end{array}$ & & $\mathrm{V}$ & & & & $\mathrm{V}$ \\
\hline - Offering candidature & $\mathrm{V}$ & $\mathrm{V}$ & $\mathrm{V}$ & Showing interest in the offer & $\mathrm{V}$ & $\mathrm{V}$ \\
\hline $\begin{array}{l}\text { Introducing } \\
\text { candidature }\end{array}$ & $\mathrm{V}$ & $\mathrm{V}$ & & & & $\mathrm{V}$ \\
\hline $\begin{array}{l}\text { Promoting } \\
\text { candidature }\end{array}$ & $\begin{array}{l}\text { Establishing } \\
\text { credentials }\end{array}$ & $\mathrm{V}$ & $\mathrm{V}$ & $\begin{array}{l}\text { Indication of the applicant's } \\
\text { professional skills. } \\
\text { Description of the } \\
\text { applicant's educational } \\
\text { background and } \\
\text { professional skills. }\end{array}$ & $\mathrm{V}$ & $\mathrm{V}$ \\
\hline & & & & $\begin{array}{l}\text { Description of the applicant's } \\
\text { positive personality traits. }\end{array}$ & & \\
\hline - Enclosing documents & $\mathrm{V}$ & $\mathrm{V}$ & $\mathrm{V}$ & & $\mathrm{V}$ & $\mathrm{V}$ \\
\hline - Willingness to action & $\begin{array}{l}\text { Soliciting } \\
\text { response }\end{array}$ & $\begin{array}{l}\text { Offering to provide } \\
\text { further information } \\
\text { Welcoming } \\
\text { response }\end{array}$ & $\begin{array}{l}\text { - Soliciting response } \\
\text { Indicating } \\
\text { willingness for } \\
\text { personal interview }\end{array}$ & Expectation of further contact & $\begin{array}{l}\text { Soliciting responses } \\
\text { (favorable) }\end{array}$ & $\mathrm{V}$ \\
\hline - Stressing the facts & & & & & & $\mathrm{V}$ \\
\hline - Praying for employer & & & & & & $\mathrm{V}$ \\
\hline - Offering service & & & & & & V \\
\hline - Thanking & Ending politely & Thanking & Ending politely & Expression of respect & Ending politely & $\mathrm{V}$ \\
\hline - Closing salutation & & & & & $\begin{array}{l}\text { Closing the } \\
\text { courtesy }\end{array}$ & $\mathrm{V}$ \\
\hline
\end{tabular}

Table 6 shows that the moves found in this research and previous studies are universal features for application letters. Those moves are: (1) Opening salutation, (2) Referring to source information (in solicited letters), (3) Offering candidature, (4) Promoting candidature, (5) Enclosing documents, (6) Willingness to action, and (7) Thanking (polite ending, closing salutation).

Regarding the second research question, the following describes the research findings of the language used in move of job application letters. Usually, many Indonesians use Dengan Hormat or Salam Hormat as the opening of letters, also in job application letters. In solicited letters, the applicants did not state the source of job vacancy information if the information was from someone who works in internal institution. See the example below for example:

Based on the information from lecturer colleagues at Economic Faculty of UXY Jakarta about the opportunity to be a lecturer of KK ,... ( S L / 11 / K 2/M)

Regarding to the information about the job vacancy, I am writing this letter to apply for the position of part time lecturer in Faculty of Economy. (SL/22/D$8 / \mathrm{M})$

But, if the job information was from website or daily newsletter, they stated the source of job information in detail or sometimes not:

Regarding to the job vacancy at Kompas newspaper, December 1st 2012, your institution needs some teaching staff.... (SL/33/D-7/M)

Regarding the information from UXY website that the institution is in demand for lecturer position at Accounting Department... (SL/41/D-7/F)
Another move of job application letter is offering candidature which expressed explicitly by almost applicants. For instance:

I want to take the chance to be a lecturer at Economic Faculty of UXY Jakarta. (SL/11/K-2/M)

With this letter, I am

Name : AN

Address : Taman Meruya Ilir

Subject to teach : International Tax and Tax Seminar, Thesis Writing Supervisor (Tax major)

Since : 2003 - present

Other activities at UXY:

Scholarship committee UXY

Since : 2008 - present writing this letter to apply for a permanent lecturer position 20 hours at Faculty of Economics, particularly in tax subject.

(US/42/D-18/F)

In promoting the abilities themselves, many candidatures did not declare them explicitly. The effective application letter should expose the applicant's qualifications and work experiences so that recruiter has a good first impression before he read the curriculum vitae completely. For example:

I, AS (with the degree), graduating in 2000 from Management Department Economic Faculty of UXY, majored in Finance Management. Right now, I am enrolling Management Master at UXY Jakarta. In the field of education, I have ever taught at Computer Laboratory of Economic Faculty for more than 5 years $(\mathrm{SL} / 11 / \mathrm{K}-2 / \mathrm{M})$

Before closing the application letter, many applicants enclose some documents such as certificates and academic transcripts, letter recommendation, and identity 
card for ensuring the recruiters about their conditions and qualifications. For example:

Completing the requirement, attached are: (1) Curriculum Vitae, (2) A copy of certificate (Bachelor's and Master's Degree), (3) A copy of writings, and some published books, and (4) Photo 3 x 4. (US/4/D-8/M)

Following the enclosing moves are willingness to action. It is used by the applicant to get attention and get action from recruiters to welcome them for interviewing, testing or just considering them, which can be seen in the following example:

I hope that you are willing to deliberate this application and invite me for the next process. (US/10/K-1/M)

I hope that you would consider my application and give me an opportunity to have a test and an interview. (US/48/VR-3/F)

The latest of application letter move is thanking or expressing gratitude. This move expressed very briefly such as Thank you. Besides, various expressions are also used, such as Thank you for your attention, Thank you for your attention and opportunity, Thank you for your attention and help.

Move of introducing candidature as well as stressing the facts appear in all the corpus of data. It was also found in Bhatia (1993) and in context of South East Asia, UK, USA (Henry \& Roseberry, 2001). Therefore, in the context of South East Asia, move of introducing candidature is generally used. It means that the applicants tend to describe his or her personal information earlier in the application letters briefly. The excerpt of introducing candidature can be seen as follows:

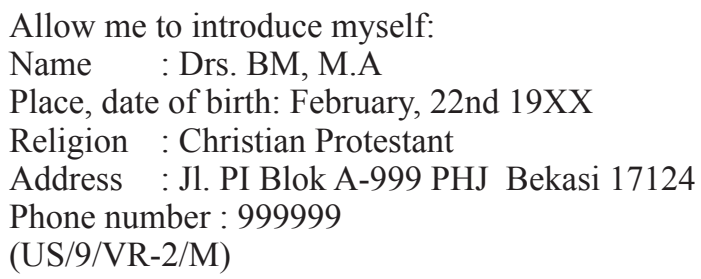

Move of stressing the facts, as a pre-closing move since it leads to the latest move of thanking, is also commonly inserted in Indonesian formal letters, such as invitation, power of attorney, and business letters. Stressing the facts can also be found in data. The following example shows the expression prior to thanking, written in Italic mode:

Thus I convey. ... Thank you for your attention. (US/58/D-9/F)

I am writing this letter in all conscience. Thank you for your attention and cooperation. (SL/37/D-12/F)

Thus I convey. Thank you for your attention.

(US/35/D-21/F)

\section{CONCLUSIONS}

The job application letter is a persuasive letter. Thus, job applicants are required to be creative in presenting the oneself very well by using effective language. Indonesian application letters contain the obligatory moves structure, i.e. opening salutation, offering candidature, introducing candidature, promoting candidature, enclosing documents, willingness to action, stressing the facts, thanking, and closing salutation.

The move structure has the similarity with the application letter from other countries as reported on previous studies (see Table 6 above). The difference lies in the label of used terms. The implicitness and inability to express self-quality could be referred to the Indonesian culture known as modesty and inhibition in telling about selves. As a result, the recruiters should find the details about job applicants through the attached supporting proof (enclosing documents), although the information is not stated explicitly in the letter. Another example, in solicited letter, the applicants do not clearly declare the source of job information if they got the information from someone who is working at the institution where they are applying.

The applicants are also expected to provide little information about his or her professionalism. It could actually motivate the recruiters to follow up their letter by calling them for the next test or interview session.

The result of this research contributes to the improvement of effective writing in Bahasa Indonesia by Indonesian native speakers. Since the culture is an important factor in genre (Martin, 1985 and Ventola, 1987 in Al-Ali, 2006), future research should involve cross-cultural research such as making comparison between Indonesian application letters and other languages in South East Asia to know the difference of moves that used by the two countries and also used for language learning. Moreover, the studies on politeness, language aspects (spelling, sentence, paragraph, cohesion, and coherence) are interesting to be fatherly investigated.

\section{REFERENCES}

Al-Ali, M. N. (2006). Genre-Pragmatic Strategies in English Letter-of-Application Writing of Jordanian ArabicEnglish Bilinguals. The International Journal of Bilingual Education and Bilingualism, 9(1), 119139.

Bhatia, V. J. (1993). Language Use in Proffessional Setting. London: Longman.

Bhatia, V. K. (n.d.). Interdiscursivity in Critical Genre Analysis. Retrieved February 24, 2015, from http:linguagem.unisul.br/paginas/ensino/pos/ linguagem/eventus/cd/English/361.pdf

Cook, G. (2011). Discourse Analysis. New York: Routledge.

Gillaerts, P. (2003). A Text Linguistic and Genological Approach to the Letter of Application. Journal of Linguistics, 31, 105-117.

Guffey, M. E., \& Du-Babcock, B. (2008). Essentials of Business Communication. Singapore: Thomson.

Henry, A., \& Roseberry, R. L. (2001). A Narrow-Angled Corpus Analysis of Moves and Strategies of the Genre: 'Letter of Application. English for Specific Purposes, 20, 153-167.

Khan, A., \& Tin, T. B. (2012). Generic Pattern in Application Letters: The Context of Pakistan. RELC Journal, 43(3), 393-410.

Nkemleke, D. (2004). Job Application and Student's Complaint Letters in Cameroon. World Englishes, 23(4), 601-611. 
Purwanto, J. (2011). Komunikasi Bisnis. Jakarta: Erlangga.

Sadeghi, V., \& Samuel, M. (2013). Genre Analysis of the Letters of Appeal. Discourse Studies, 15(2), 229245.

Soroko, E. (2012). The Presentation of Self in Letters of Application: A Mixed-Method Approach. Journal of Employement Counseling, 49, 4-17.

Swales, J. M. (1990). Genre Analysis English in Academic and Research Settings. Cambridge: Cambridge University Press. 